\title{
A identidade profissional do professor: um estudo de revisão sistemática
}

CDD. 20.ed. 370.71

375.76

796

\author{
Patrícia Maria Silva GOMES* \\ Cátia Patrícia Pereira FERREIRA* \\ Ana Luísa PEREIRA* \\ Paula Maria Fazendeiro BATISTA*
}

*Faculdade do Desporto, Universidade do Porto - Portugal.

\section{Resumo}

0 presente estudo é uma revisão sistemática da literatura cujo objetivo foi cartografar a tipologia de estudos empíricos realizados acerca da Identidade Profissional do professor. A pesquisa foi efetuada nas bases de dados eletrônicas ISI Web of Knowledge, ERIC, SPORTDiscus e SCOPUS entre 2001 e 2012. As equações de pesquisa foram "Professional Identity" AND "Teacher", no campo título e "Professional Identity" AND "Teacher" AND "Physical Education", no campo "Abstract", tendo sido integrados 42 artigos. A análise de conteúdo, com categorias definidas "a priori", foi a técnica utilizada: a) foco do estudo; b) ano e local de publicação; c) objetivos; d) participantes; e) instrumentos e f) principais conclusões. Os resultados evidenciaram um aumento da pesquisa na área e nas metodologias qualitativas. Estas colocam o desenvolvimento profissional como elemento central no processo de (re)construção da Identidade Profissional, sendo que ao nivel do professor de Educação Física a pesquisa ainda é escassa.

Palavras-chave: Identidade profissional; Professor; Desenvolvimento profissional; Educação física; Revisão sistemática da literatura.

\section{Introdução}

O professor, independentemente das alterações que ocorram no ensino e na educação, tem sido e continuará a ser considerado um elemento central na e à sociedade. Neste entendimento, FONTES et al. ${ }^{1}$ consideram que o questionamento centrado na figura do professor, designadamente por recurso à problemática da construção social da sua identidade, deve ocupar um espaço significativo da pesquisa na área das ciências da educação.

Importa referir, em primeiro lugar, que quando se fala em identidade, entende-se a identidade como um processo contínuo e dinâmico, que implica a criação de sentido e (re)interpretação dos próprios valores e experiências ${ }^{2}$. Já $\mathrm{GEE}^{3}$ advoga que a identidade está relacionada com o ser-se reconhecido por si e pelos outros como um "certo tipo de pessoa", num determinado contexto e na relação com os outros. Para o mesmo autor, trata-se de um processo que envolve quatro dimensões distintas, mas em interação: a identidade natural (reporta-se à origem do indivíduo no sentido dos atributos herdados) a identidade institucional (refere-se à posição ocupada pelo indivíduo numa determinada estrutura organizacional, à qual estão inerentes direitos e responsabilidades); a identidade discursiva (compreende as características pessoais que marcam a individualidade da pessoa na relação com os outros) e a identidade de filiação (materializa-se no acesso a um conjunto de práticas distintas que são do interesse comum de um determinado grupo de afinidade, as quais permitem a integração das pessoas pela participação e partilha dessas práticas especificas).

Por sua vez, $\mathrm{SACHS}^{4}$, ao reportar-se à aquisição da identidade do professor, refere que tornar-se professor envolve a (trans)formação da identidade docente num processo que é descrito como aberto, negociado e dinâmico.

Desta forma, para compreender como se configura e se transforma a Identidade Profissional do professor, é necessário esclarecer os processos através dos quais 
esta se constrói e se reconstrói ao longo da vida. Com efeito, a Identidade Profissional é uma identidade social particular, entre outras identidades sociais da pessoa, mas que decorre no lugar das profissōes ${ }^{5}$ (p.279). Já para DubaR ${ }^{6}$, as Identidades Profissionais são identidades "especializadas" que dizem respeito a atividades, também elas especializadas, ou seja, respeitantes a mundos institucionais específicos ligados a saberes especializados e a papéis mais ou menos ligados com a divisão social do trabalho. De fato, o professor conquista espaço para desenvolver o seu trabalho, embora de forma institucionalizada pela identidade coletiva, ou seja, padronizado pelas particularidades da docência, congregando na sua identidade social e pessoal a sua Identidade Profissional. Assim, tal como advoga JuRASAITE-HaRBISON ${ }^{7}$, é crucial a investigação acerca da Identidade Profissional, com base na ideia de que esta resulta de uma interface entre as experiências pessoais dos professores e o contexto social, cultural e institucional do seu quotidiano.

Partindo deste enquadramento e considerando que o processo de formação do professor também, ele, é um processo de socialização, pode inferir-se que as interaçôes sociais são elementos que contribuem para a construção da identidade, pela criação de um sentimento de pertença a um grupo. A prática profissional surge, naturalmente, como um elemento central em todo este processo de desenvolvimento. De fato, a construção da Identidade Profissional depende, indubitavelmente, de um contexto de ação, que exige constantes adaptações, numa perspetiva prática e reflexiva de natureza individual e coletiva. Desta forma, ter acesso ao modo como cada pessoa se forma é ter em conta a singularidade da sua história e, sobretudo, o modo singular como age, reage e interage com os outros e com o contexto. Com efeito, como afirmam Pimenta e AnASTASIOU ${ }^{8}$, a construção da identidade docente baseia-se nos valores de cada indivíduo, no modo como cada um constrói as suas histórias, no modo como cada um se situa no mundo enquanto professor, nas suas representações, nos seus saberes, nas suas angústias e anseios. Assim, e segundo DUBAR ${ }^{6}$, discutir a profissão e a profissionalização docente requer que se trate as questōes relativas à construção da sua identidade, vista como resultado "simultaneamente estável e provisório, individual e coletivo, subjetivo e objetivo, biográfico e estrutural dos diversos processos de socialização que simultaneamente constroem os indivíduos e definem as instituiçôes" (p.111).

Face ao exposto, o processo de construção da Identidade Profissional afigura-se como um processo complexo que importa conhecer mais aprofundadamente, pois é pelo entendimento dos fenômenos que é possível melhorar os processos, neste caso o processo de construção da Identidade Profissional docente. Deste modo, o presente estudo teve como propósito mapear os estudos efetuados acerca das questóes da Identidade Profissional do professor e do professor de Educação Física em particular, bem como identificar os fatores que são apontados pela investigação como contributos para o desenvolvimento da Identidade Profissional.

\section{Método}

Sendo a revisão sistemática da literatura um meio rigoroso de sintetizar e incrementar o conhecimento da literatura relevante, clarificando temas, indicando tópicos para pesquisas futuras e priorizando as temáticas que carecem de maior investimento ${ }^{9-10}$, este estudo procurou, através dos contributos dos estudos individuais, fornecer uma visão da investigação existente no campo da Identidade Profissional do professor, mais especificamente do professor de Educação Física.

O primeiro passo efetuado foi a construção de uma ficha de pesquisa, tendo como referência KoFINAS e SAUR-AMARAL ${ }^{11}$, cujo propósito foi sistematizar os critérios de pesquisa da revisão sistemática a efetuar, a equação e o âmbito da pesquisa, bem como, definir os critérios de inclusão e exclusão no decorrer da pesquisa (QUADRO 1). A ficha de pesquisa foi aplicada de forma independente por duas investigadoras.

Como se pode observar na ficha de pesquisa os estudos foram recolhidos de quatro bases de dados eletrônicas (ISI Web of Knowledge; ERIC; SPORTDiscus e SCOPUS), utilizando numa primeira fase a equação de pesquisa: "Professional Identity" AND "teacher", no campo "Título" e posteriormente, face ao propósito adicional que pretendia identificar estudos na área da Educação Física, a pesquisa foi aprofundada recorrendo a uma segunda equação "Professional Identity" AND "teacher" AND "Physical Education" e alargada ao campo "Abstract".

$\mathrm{Na}$ primeira fase, no âmbito geral da Identidade Profissional do professor, da pesquisa efetuada na base de dados ISI Web of Knowledge resultaram 48 
artigos, onde das 37 produções científicas, somente 27 atendiam aos critérios de inclusão: artigos publicados em jornais com "peer review", escritos em inglês e no âmbito da temática em foco. Seguidamente, da pesquisa realizada nas bases de dados ERIC e SPORTDiscus resultaram 28 artigos, que após refinamento, com os mesmos critérios, resultaram em apenas 17 artigos. Relativamente à base de dados SCOPUS na primeira fase foram identificados 66 estudos, que após aplicação dos critérios, foram reduzidos a 25 artigos. $\mathrm{Na}$ fase terminal, procedeu-se à eliminação dos artigos duplicados, resultantes das quatro bases de dados, tendo-se obtido um total de 41 artigos. Contudo, após a leitura do texto integral foram ainda excluídos três estudos por serem capítulos de livros e dois artigos por não serem estudos de natureza empírica, resultando, assim, num total de 36 artigos.

$\mathrm{Na}$ segunda fase da pesquisa, centrada na Educação Física e alargada ao campo "abstract", na base de dados ISI resultaram quatro artigos, tendo permanecido apenas três, quando aplicados os critérios de inclusão e de exclusão. $\mathrm{Na}$ base de dados da ERIC e SPORTDiscus apenas foi identificado um estudo. Já na base de dados SCOPUS, dos oito artigos identificados, apenas seis corresponderam aos critérios. Após a eliminação dos artigos duplicados desta segunda fase da pesquisa nas quatro bases de dados, obteve-se um total de sete artigos. Após a leitura integral dos artigos foi excluído um artigo, porquanto os objetivos não se relacionavam com a temática da Identidade Profissional do professor. Desta forma, da junção de ambas as pesquisas obteve-se um total de 42 artigos, na qual 36 estudos emergiram da primeira equação de pesquisa, confinada ao campo "Título", acerca da Identidade Profissional do Professor, e seis estudos resultaram da segunda equação de pesquisa, alargada ao campo "Abstract", referente à Identidade Profissional do Professor de Educação Física.

$\mathrm{Na}$ análise da informação utilizaram-se procedimentos de análise de conteúdo, tendo as categorias sido estabelecidas "a priori": a) foco do estudo; b) ano e local de publicação; c) instrumentos; d) objetivos; e e) principais conclusões.

Para apresentação e discussão dos resultados utilizou-se a síntese narrativa, um dos métodos mais utilizados nas Revisões Sistemáticas da Literatura ${ }^{12}$. Neste contexto, seguiram-se os passos elencados pelos autores: a) organizar a descrição dos estudos em categorias lógicas; b) analisar os resultados dentro de cada categoria; c) sintetizar os resultados transversais aos estudos.

QUADRO 1-Ficha de pesquisa da revisão sistemática acerca da identidade profissional do professor.

\begin{tabular}{|c|c|}
\hline Conteúdo & Explicaçáo \\
\hline Objetivo da pesquisa & $\begin{array}{l}\text { Identificar a tipologia de estudos empíricos realizados acerca da Identidade Profissional e os elemen- } \\
\text { tos associados ao desenvolvimento da Identidade Profissional do professor. }\end{array}$ \\
\hline $\begin{array}{l}\text { Equação de pesquisa } \\
\text { a experimentar }\end{array}$ & $\begin{array}{l}\text { "Professional Identity" AND “teacher". } \\
\text { "Professional Identity" AND "teacher" AND "Physical Education". }\end{array}$ \\
\hline Âmbito da pesquisa & $\begin{array}{l}\text { A pesquisa será realizada na ISI Web of Knowledge, ERIC, SPORTDiscus e SCOPUS, focada nos } \\
\text { artigos publicados nos últimos } 11 \text { anos (de } 2001 \text { a 2012), no campo de procura Título para a pri- } \\
\text { meira equação e no campo "Abstract" para a segunda equação de pesquisa. }\end{array}$ \\
\hline Critérios de inclusão & $\begin{array}{l}\text { Somente serão considerados artigos empíricos publicados em jornais com "peer review", pelo fato } \\
\text { destes serem fontes de informação científica reconhecidas pela comunidade acadêmica associada às } \\
\text { ciências sociais e humanas. Serão apenas incluídos os trabalhos publicados que envolvem as grandes } \\
\text { temáticas: "Teacher", "Education", "Educational"; "Professional Development" e "Identity". }\end{array}$ \\
\hline Critérios de exclusão & $\begin{array}{l}\text { Artigos sem "abstract” e sem texto integral. } \\
\text { Artigos publicados em livros, conferências, etc. } \\
\text { Artigos de revisão de literatura e náo relacionados com o tema em causa ou publicados em revistas } \\
\text { fora do âmbito do assunto mencionado. } \\
\text { Artigos escritos em outra língua que não inglês. }\end{array}$ \\
\hline $\begin{array}{l}\text { Critérios de } \\
\text { qualidade e validade } \\
\text { metodológica }\end{array}$ & $\begin{array}{l}\text { A presente ficha de pesquisa será utilizada independentemente por duas investigadoras. Caso estas } \\
\text { cheguem a resultados diferentes, os mesmos deverão ser identificados e explicados. } \\
\text { Os critérios de inclusão e exclusão serão aplicados com rigor. } \\
\text { Todos os passos da pesquisa serão registados e a aplicaçáo dos critérios justificada. }\end{array}$ \\
\hline
\end{tabular}

Fonte: adaptado de KofINAS e SAUR-AmARAL ${ }^{11}$ 


\section{Resultados}

$\mathrm{Na}$ organização dos resultados optou-se por apresentá-los em duas grandes componentes, sendo que na primeira são analisados os estudos resultantes da primeira pesquisa acerca da Identidade Profissional do professor e na segunda os estudos referentes à Identidade Profissional do professor de Educação Física. Em ambas as componentes a sequência de análise foi: 1) participantes dos estudos; 2) cronologia e locais onde foram realizados os estudos; 3) instrumentos utilizados para o seu desenvolvimento; e por fim 4) as principais conclusões.

\section{Identidade profissional do professor}

A primeira fase da pesquisa permitiu integrar 36 estudos empíricos, cuja sinopse está descrita no QUADRO 2.

QUADRO 2 - Sinopse de estudos relativos à identidade profissional do professor.

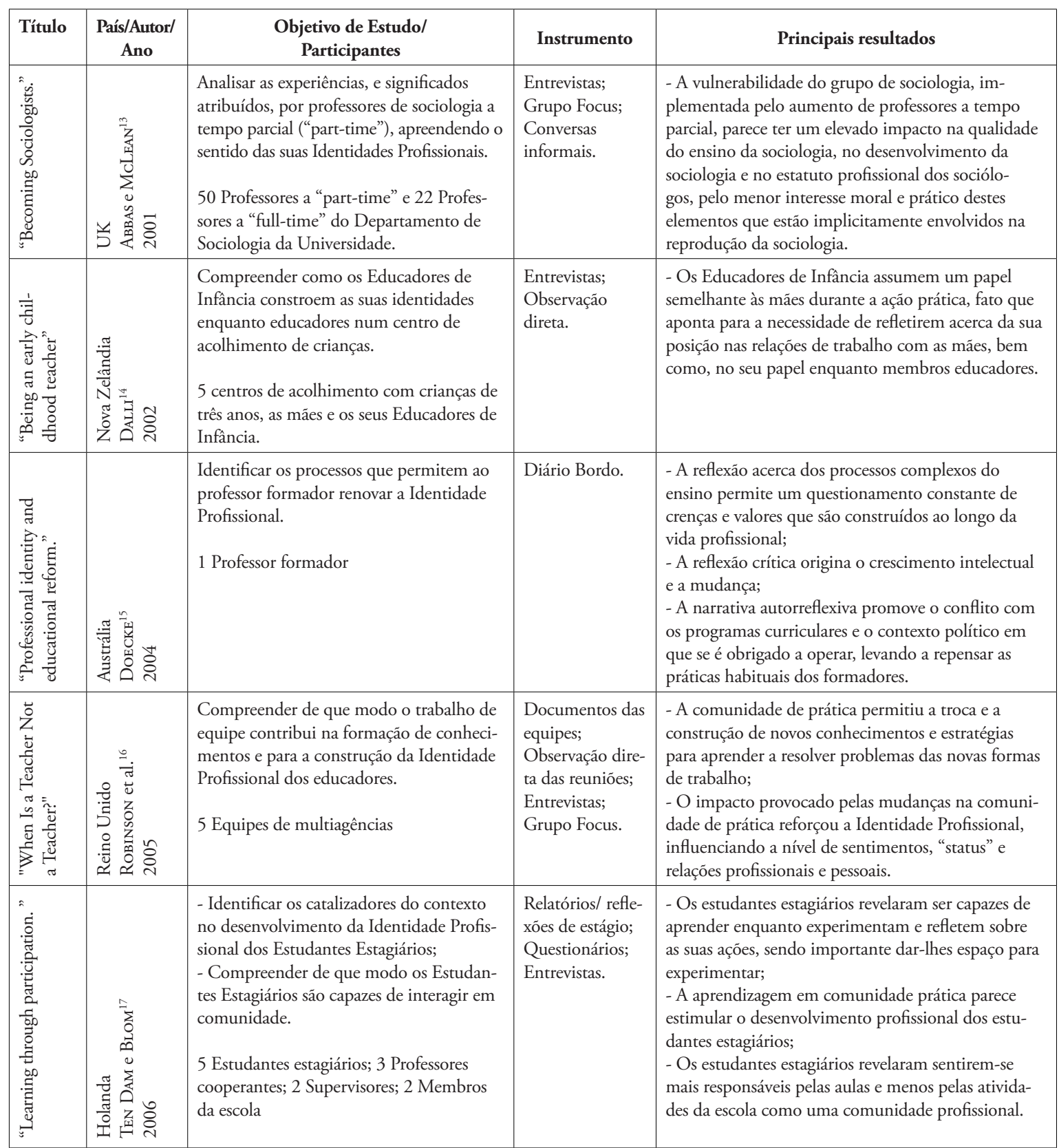


QUADRO 2 - Sinopse de estudos relativos à identidade profissional do professor (continuação).

\begin{tabular}{|c|c|c|c|c|}
\hline Título & $\begin{array}{c}\text { País/Autor/ } \\
\text { Ano }\end{array}$ & $\begin{array}{c}\text { Objetivo de Estudo/ } \\
\text { Participantes }\end{array}$ & Instrumento & Principais resultados \\
\hline 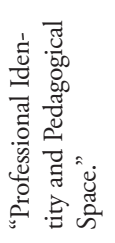 & 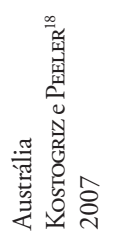 & $\begin{array}{l}\text { Compreender a "luta espacial" na } \\
\text { formação de Identidades Profissionais dos } \\
\text { professores estrangeiros. } \\
9 \text { Professoras de diferentes nacionalidades }\end{array}$ & Entrevistas. & $\begin{array}{l}\text { - Os autores advogam que a "comunidade" é uma } \\
\text { construçâo ambivalente que tanto une as pessoas } \\
\text { como cria limites e barreiras que mantêm o "out- } \\
\text { sider", o estranho e o estrangeiro de parte. Assim, } \\
\text { comunidade profissional de professores é considerada } \\
\text { simultaneamente inclusiva e exclusiva, porque é } \\
\text { produzida como um espaço imaginário e abstrato. }\end{array}$ \\
\hline 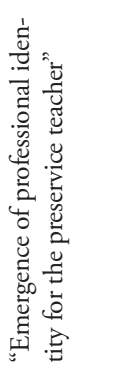 & 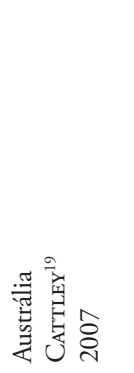 & $\begin{array}{l}\text { Identificar os fatores que influenciam a } \\
\text { construção de uma Identidade Profissional } \\
\text { sólida dos Estudantes Estagiários, durante } \\
\text { o estágio, e quais podem ser indicadores } \\
\text { da Identidade Profissional. } \\
8 \text { Estudantes estagiários }\end{array}$ & $\begin{array}{l}\text { Registros } \\
\text { reflexivos dos EE } \\
\text { ("Reflective Log } \\
\text { Proforma”). }\end{array}$ & $\begin{array}{l}\text { - O incentivo à reflexão acerca do papel mul- } \\
\text { tifacetado do professor, dentro e fora de aula, } \\
\text { reconhecendo emoçóes e responsabilidades, parece } \\
\text { influenciar a construçáo da Identidade Profissional } \\
\text { dos estudantes estagiários; } \\
\text { - A autora refere como principais indicadores da } \\
\text { Identidade Profissional: a relação com os outros; } \\
\text { a consciência do mundo social e político além da } \\
\text { sala de aula; a consciência da partilha e da ajuda; a } \\
\text { consciência dos benefícios da observação (eu e os } \\
\text { outros) e análise das próprias açóes. }\end{array}$ \\
\hline 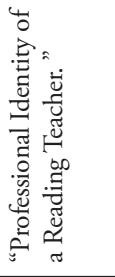 & 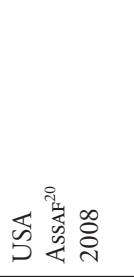 & $\begin{array}{l}\text { Analisar a Identidade Profissional de uma } \\
\text { especialista em leitura quando confrontada } \\
\text { com as decisôes e práticas institucionaliza- } \\
\text { das na preparaçáo dos alunos para o teste } \\
\text { de um Programa de ensino em Inglês. } \\
1 \text { professora especialista em leitura. }\end{array}$ & $\begin{array}{l}\text { Notas de campos; } \\
\text { Entrevistas; } \\
\text { Documentos } \\
\text { informativos do } \\
\text { programa } \\
\text { (Método etnográ- } \\
\text { fico com observa- } \\
\text { çáo participante). }\end{array}$ & $\begin{array}{l}\text { - A análise do estudo depreende que a professora dá } \\
\text { prevalência ao compromisso de ajudar os alunos na } \\
\text { preparaçáo para o teste, apresentando dificuldades } \\
\text { em se manter fiel à sua Identidade Profissional; } \\
\text { - A pressão institucionalizada parece influenciar a } \\
\text { capacidade de resposta da professora às necessida- } \\
\text { des dos alunos e comprometer a responsabilidade e } \\
\text { sentido ético do que é ser professor. }\end{array}$ \\
\hline 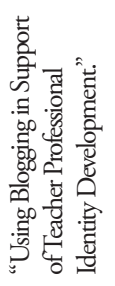 & 光密号 & $\begin{array}{l}\text { Identificar como o uso e a prática narra- } \\
\text { tiva do blogue pode beneficiar a prática } \\
\text { docente. } \\
1 \text { professora }\end{array}$ & $\begin{array}{l}\text { Blogue; } \\
\text { E-mail. }\end{array}$ & $\begin{array}{l}\text { - O uso do blogue deu oportunidade à professora } \\
\text { de contar as estórias da sua aula, permitindo-lhes } \\
\text { refletir sobre as suas práticas, trabalhar com proble- } \\
\text { mas comuns a vários professores, solicitar ajuda e } \\
\text { facilitar a troca de competências e ideias. }\end{array}$ \\
\hline 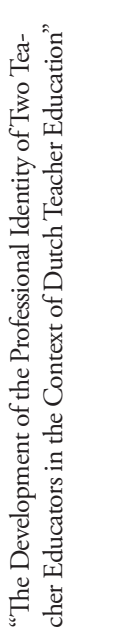 & 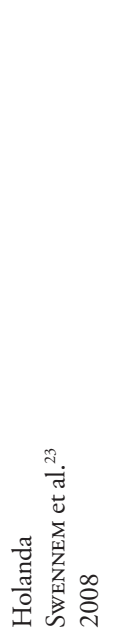 & $\begin{array}{l}\text { Compreender o modo como as professoras } \\
\text { desenvolvem a identidade na formação } \\
\text { de professores primários e como é que } \\
\text { esse desenvolvimento influencia o recente } \\
\text { desenvolvimento da educação primária. } \\
2 \text { professoras universitárias de ensino } \\
\text { primário. }\end{array}$ & $\begin{array}{l}\text { Narrativas } \\
\text { biográficas. }\end{array}$ & $\begin{array}{l}\text { - Os autores compreenderam que inicialmente o } \\
\text { desenvolvimento das identidades profissionais das } \\
\text { professoras, como formadoras de professores, foi } \\
\text { apreendido e suportado de forma dedutiva pelas suas } \\
\text { instituições mas foi no seu desempenho diário, na } \\
\text { conquista de novos conhecimentos e habilidades que } \\
\text { as suas identidades foram sendo (re)construídas; } \\
\text { - Gradualmente, os formadores de professores multi- } \\
\text { plicaram as tarefas e funçốes, sendo que a par destas } \\
\text { mudanças as formadoras sentiram ser indispensável } \\
\text { procurar novos conhecimentos e, consequentemen- } \\
\text { te, desenvolveram as suas identidades profissionais } \\
\text { como resposta às necessidades formativas; } \\
\text { - O desenvolvimento profissional das professo- } \\
\text { ras resulta das próprias ambiçóes e sentidos de } \\
\text { iniciativa, às vezes desencadeadas pelo Governo e } \\
\text { apoio financeiro. Contudo, as instituiçóes parecem } \\
\text { limitar a inovaçấo na formação e o desenvolvimen- } \\
\text { to das identidades profissionais dos formadores. }\end{array}$ \\
\hline
\end{tabular}

Continua 
QUADRO 2 - Sinopse de estudos relativos à identidade profissional do professor (continuação).

\begin{tabular}{|c|c|c|c|c|}
\hline Título & $\begin{array}{l}\text { País/Autor/ } \\
\text { Ano }\end{array}$ & $\begin{array}{c}\text { Objetivo de Estudo/ } \\
\text { Participantes }\end{array}$ & Instrumento & Principais resultados \\
\hline 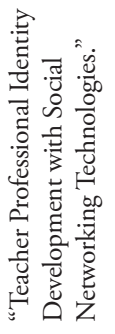 & 至 & $\begin{array}{l}\text { Verificar como o uso do blogue permite } \\
\text { interaçóes significantes entre os profissio- } \\
\text { nais docentes. } \\
15 \text { Professores de ciências do ensino } \\
\text { secundário }\end{array}$ & $\begin{array}{l}\text { Blogue; } \\
\text { Questionários. }\end{array}$ & $\begin{array}{l}\text { - O uso do blogue permite aos utilizadores expor as } \\
\text { suas ideias e práticas, desenvolvendo a coopera- } \\
\text { ção, o incentivo, a interpretação e aceitação de } \\
\text { conselhos transmitidos pelos comentários de outros } \\
\text { utilizadores. }\end{array}$ \\
\hline 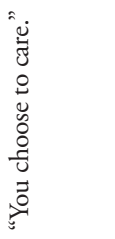 & 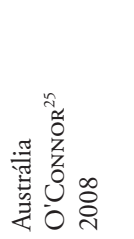 & $\begin{array}{l}\text { Analisar a Identidade Profissional de } \\
\text { professores do ensino secundário quanto } \\
\text { às decisōes tomadas na interação afetiva } \\
\text { com os alunos e às suas experiências } \\
\text { emocionais. } \\
3 \text { Professores de ensino secundário }\end{array}$ & Entrevistas. & $\begin{array}{l}\text { - O comportamento carinhoso que os professores } \\
\text { assumem revela dimensóes profissionais, perfor- } \\
\text { mativas e filosóficas, porquanto necessitam de } \\
\text { ser autônomos perante as demandas que lhes são } \\
\text { colocadas em diferentes contextos. }\end{array}$ \\
\hline 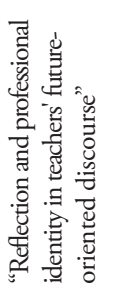 & 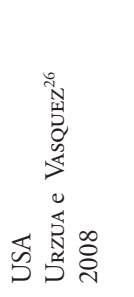 & $\begin{array}{l}\text { Analisar a relação do discurso de professo- } \\
\text { res principiantes de um programa intensi- } \\
\text { vo de Inglês, em reuniôes de orientação, e } \\
\text { o pensamento reflexivo na construção da } \\
\text { Identidade Profissional. } \\
16 \text { Professores principiantes (Programa } \\
\text { Intensivo de Inglês). }\end{array}$ & $\begin{array}{l}\text { Gravação áudio } \\
\text { das reunióes } \\
\text { de orientação } \\
\text { (mentor, super- } \\
\text { visor e professor } \\
\text { principiante). }\end{array}$ & $\begin{array}{l}\text { - As reuniōes de orientação parecem representar es- } \\
\text { paços discursivos em que os professores principian- } \\
\text { tes têm a oportunidade de verbalizar planos, prever } \\
\text { os resultados, analisar as possibilidades e refletir } \\
\text { sobre suas práticas pedagógicas em evolução. Por } \\
\text { isso, os professores mentores devem ter consciência } \\
\text { da importância destas funções e incentivar a refle- } \\
\text { xão prospetiva dos professores principiantes. }\end{array}$ \\
\hline 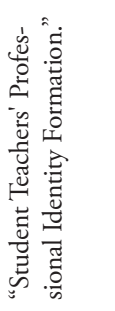 & 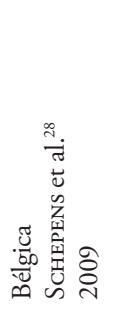 & $\begin{array}{l}\text { Compreender de que modo as variáveis } \\
\text { de entrada (características demográficas, } \\
\text { personalidade e motivaçôes) e o contexto } \\
\text { de formaçáo influenciam a construçáo da } \\
\text { Identidade Profissional. } \\
762 \text { Licenciados na formação de profes- } \\
\text { sores }\end{array}$ & Questionários. & $\begin{array}{l}\text { - As variáveis independentes em estudo têm maior } \\
\text { influência no compromisso de ensino e menos na } \\
\text { autoeficácia, seguido da orientaçáo profissional; } \\
\text { - A Identidade Profissional revelou ser uma assimi- } \\
\text { lação do que é individual e coletivamente conside- } \\
\text { rado relevante, sendo que é muito influenciada pe- } \\
\text { las variáveis de entrada (personalidade e motivaçôes } \\
\text { para a docência) e pelo senso de responsabilidade e } \\
\text { preparaçáo para a docência. }\end{array}$ \\
\hline 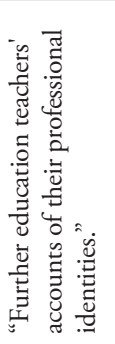 & 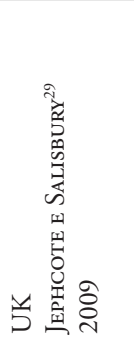 & $\begin{array}{l}\text { Explorar as condiçóes em que os professores } \\
\text { de ensino superior trabalham, as suas } \\
\text { interaçóes com os alunos e o modo como } \\
\text { constroem as suas identidades profissionais. } \\
27 \text { Professores universitários } \\
45 \text { Estudantes }\end{array}$ & $\begin{array}{l}\text { Entrevistas; } \\
\text { Observação } \\
\text { etnográfica; } \\
\text { Relatos Biográ- } \\
\text { ficos. }\end{array}$ & $\begin{array}{l}\text { - Se por um lado os professores estavam cada vez } \\
\text { mais sujeitos a normas externas e códigos de práti- } \\
\text { ca, por outro exerciam o seu próprio agenciamen- } \\
\text { to, no controle e na construçấo das suas próprias } \\
\text { identidades profissionais. } \\
\text { - Esta pressão sentida pelos professores provocava } \\
\text { mudanças nas suas performances e uma constante } \\
\text { destabilização nos seus trabalhos, contudo, os } \\
\text { professores participantes privilegiavam mais as } \\
\text { necessidades e os interesses de seus alunos. }\end{array}$ \\
\hline
\end{tabular}


QUADRO 2 - Sinopse de estudos relativos à identidade profissional do professor (continuação).

\begin{tabular}{|c|c|c|c|c|}
\hline Título & $\begin{array}{c}\text { País/Autor/ } \\
\text { Ano }\end{array}$ & $\begin{array}{c}\text { Objetivo de Estudo/ } \\
\text { Participantes }\end{array}$ & Instrumento & Principais resultados \\
\hline 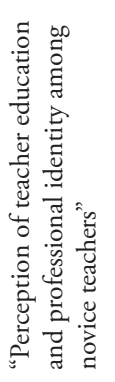 & 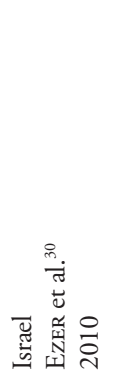 & $\begin{array}{l}\text { Identificar as perceções dos estudantes } \\
\text { estagiários durante o estágio, quanto à } \\
\text { profissão e ao papel do professor, quanto } \\
\text { à sua formação e à sua identidade como } \\
\text { professores. } \\
97 \text { Professores estagiários }\end{array}$ & Questionários. & $\begin{array}{l}\text { - Os autores consideram que a motivaçáo intrínse- } \\
\text { ca para o ensino é maior que a extrínseca; } \\
\text { - A análise aos questionários revela que o papel } \\
\text { docente, considerado mais importante, é o ensino } \\
\text { de valores universais (respeito, responsabilidade e } \\
\text { comprometimento); } \\
\text { - A experiência e os estudos didáticos foram as com- } \\
\text { ponentes identificadas como mais significativas; } \\
\text { - Os agentes apontados como mais relevantes foram } \\
\text { os professores das didáticas e o professor mentor. }\end{array}$ \\
\hline & 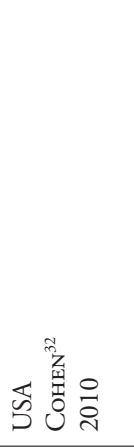 & $\begin{array}{l}\text { Identificar as estratégias discursivas usadas } \\
\text { pelos professores para negociar significados } \\
\text { locais para as suas identidades profissio- } \\
\text { nais. } \\
3 \text { Professoras de Humanidades }\end{array}$ & $\begin{array}{l}\text { Observação } \\
\text { etnográfica; } \\
\text { Conversas } \\
\text { Informais; } \\
\text { "Audiotaping"; } \\
\text { "Workshops"; } \\
\text { Grupo Focus. }\end{array}$ & $\begin{array}{l}\text { - A análise aos resultados revela que os professores } \\
\text { reconhecem-se como alunos frente aos desafios } \\
\text { educacionais que lhes são colocados no local, pois } \\
\text { necessitam de vincular suas açóes, valores e dispo- } \\
\text { siçóes ao contexto, apresentando uma identidade } \\
\text { implícita numa aprendizagem que é contínua; } \\
\text {-Ao assumirem esta identidade os professores } \\
\text { utilizaram uma série de estratégias discursivas, } \\
\text { incluindo dois géneros de conversa reflexiva ("per- } \\
\text { sonal storytelling" e "analytical talk"); } \\
\text {-Os resultados destacam a importância do diálogo } \\
\text { reflexivo como uma prática profissional comparti- } \\
\text { lhada entre professores. }\end{array}$ \\
\hline 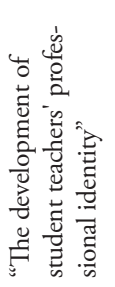 & 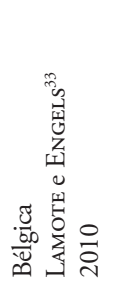 & $\begin{array}{l}\text { Analisar as percepçóes da Identidade } \\
\text { Profissional de estudantes em formaçáo de } \\
\text { professores. } \\
\text { Estudantes em formação docente dos três } \\
\text { anos de Bacharel ( } 64 \text { participantes no } 1^{\circ} \\
\text { ano; } 61 \text { no } 2^{\circ} \text { ano; e } 32 \text { no } 3^{\circ} \text { ano) }\end{array}$ & Questionários. & $\begin{array}{l}\text { - A análise do estudo depreende que ao longo da } \\
\text { formação, os estudantes desenvolvem uma visão do } \\
\text { ensino mais centrada no aluno. Simultaneamente, } \\
\text { ocorre uma descentralização relativamente à preocu- } \\
\text { pação de organizar a sala de aula e de autoeficácia, } \\
\text { concentrando-se na qualificação escolar dos alunos; } \\
\text { - Os estudantes com experiência de estágio apresen- } \\
\text { tam uma visão mais realista em relação aos restantes. }\end{array}$ \\
\hline 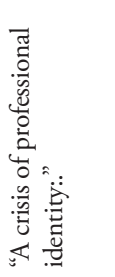 & 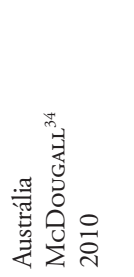 & $\begin{array}{l}\text { Analisar os discursos que emergem nas } \\
\text { entrevistas a um grupo de professores que } \\
\text { falam acerca das suas reaçóes aos meios } \\
\text { de ensino. } \\
26 \text { Professores primários australianos }\end{array}$ & Entrevistas. & $\begin{array}{l}\text { - Os discursos aplicados ao conceito de identidade } \\
\text { remetem para uma crise de identidade, uma vez que } \\
\text { apresentam duas perspetivas distintas entre os professores: } \\
\text {. Uma visão tradicionalista de quem vê os meios de } \\
\text { ensino como um fardo desnecessário; } \\
\text {. Uma visão para o futuro daqueles que "abraçam" } \\
\text { a profissão, reconhecendo, por isso, a necessidade } \\
\text { de mudar as prioridades de aprendizagem. }\end{array}$ \\
\hline 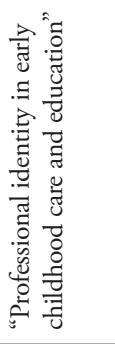 & 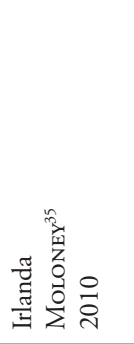 & $\begin{array}{l}\text { Analisar as percepçóes da Identidade Pro- } \\
\text { fissional dos professores do pré-escolar e } \\
\text { ensino primário, na República da Irlanda, } \\
\text { relativamente às condições e exigências de } \\
\text { trabalho. } \\
56 \text { Professores do pré-escolar e ensino } \\
\text { primário }\end{array}$ & Entrevistas. & $\begin{array}{l}\text { - A Identidade Profissional parece ser uma constru- } \\
\text { ção controversa e problemática, uma vez que: } \\
\text {. Aos professores do nível pré-escolar náo exigem } \\
\text { uma formação obrigatória; } \\
\text {. Ao nível da escola primária, a Identidade Profissio- } \\
\text { nal é comprometida pelos contextos de cada escola; } \\
\text { Os professores têm a percepçáo de que à classe docente } \\
\text { do nível infantil está associado o recreio e, por isso, } \\
\text { sentem que não recebem o mesmo respeito que os } \\
\text { professores que lecionam níveis de escolaridade superior. }\end{array}$ \\
\hline
\end{tabular}

Continua 
QUADRO 2 - Sinopse de estudos relativos à identidade profissional do professor (continuação).

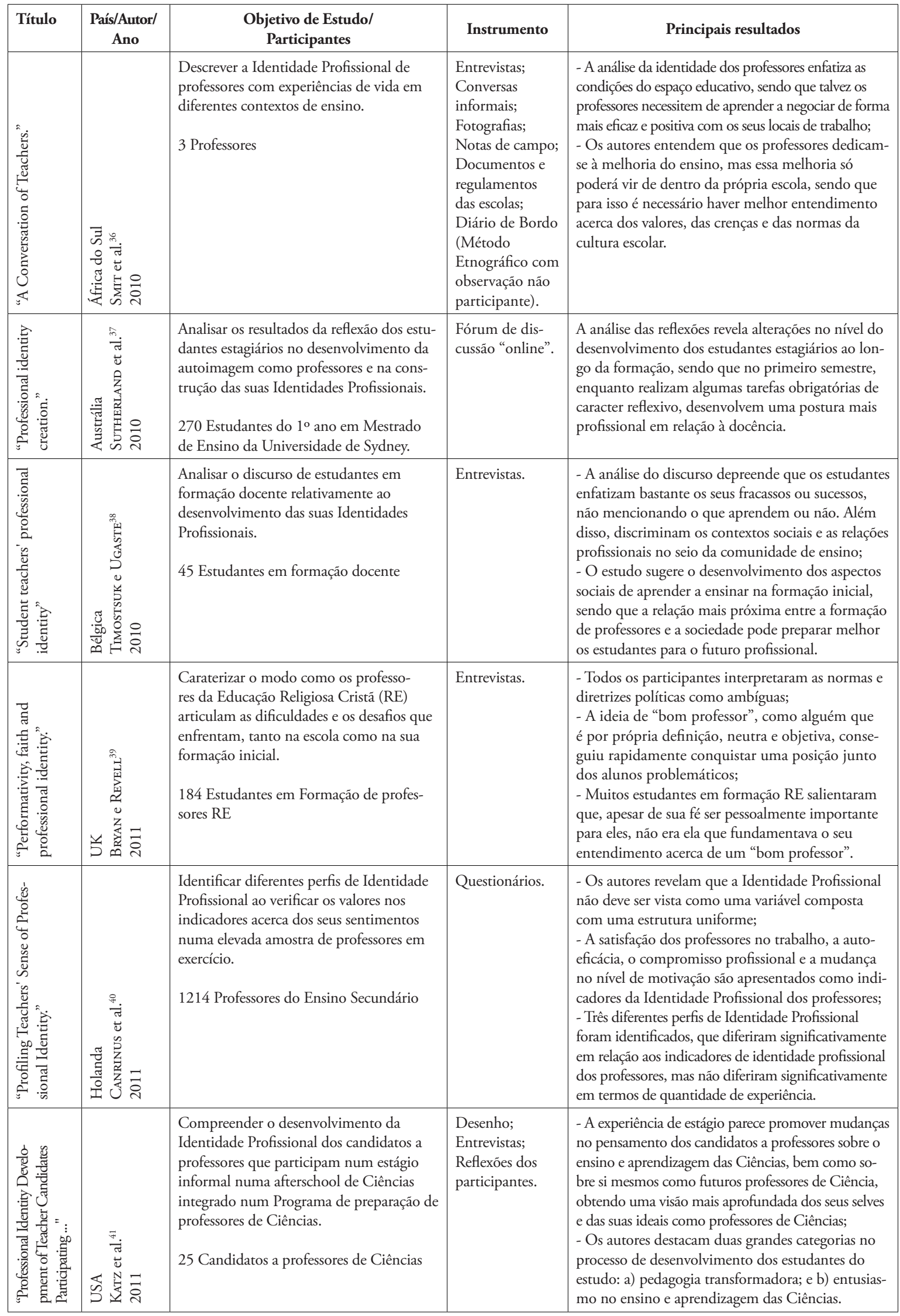


QUADRO 2 - Sinopse de estudos relativos à identidade profissional do professor (continuação).

\begin{tabular}{|c|c|c|c|c|}
\hline Título & $\begin{array}{l}\text { País/Autor/ } \\
\text { Ano }\end{array}$ & $\begin{array}{l}\text { Objetivo de Estudo/ } \\
\text { Participantes }\end{array}$ & Instrumento & Principais resultados \\
\hline 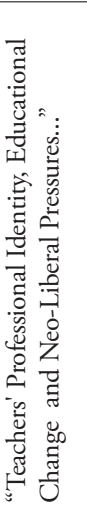 & 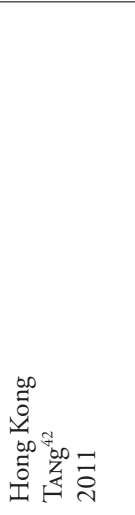 & $\begin{array}{l}\text { Analisar o impacto das mudanças educa- } \\
\text { cionais, ao longo dos períodos em Hong } \\
\text { Kong, na vida e na Identidade Profissional } \\
\text { dos professores. } \\
23 \text { Professores de três geraçóes }\end{array}$ & $\begin{array}{l}\text { Narrativas (his- } \\
\text { tórias de vida); } \\
\text { Entrevistas; } \\
\text { Análise docu- } \\
\text { mental. }\end{array}$ & $\begin{array}{l}\text { - A tendência neoliberal em Hong Kong moldou as } \\
\text { suas reformas educativas a um padrão semelhante } \\
\text { aos restantes países Ocidentais; } \\
\text { - As mudanças educativas em Hong Kong } \\
\text { materializaram-se em três temas: a) mudanças } \\
\text { nas condiçóes estruturais da carreira docente; b) a } \\
\text { natureza mutante do trabalho dos professores; e c) a } \\
\text { natureza da mudança educacional; } \\
\text { - As pressóes neoliberais desencadearam um ensino } \\
\text { cujos contextos de trabalho são caracterizados pela } \\
\text { incerteza, pela intensificaçáo de trabalho e por } \\
\text { mandatos externos que tiram aos professores muito } \\
\text { tempo e energia nos principais processos de ensino; } \\
\text { - Estas práticas parecem ameaçar o "desenvolvimento } \\
\text { sustentável" da Identidade Profissional dos professores. }\end{array}$ \\
\hline 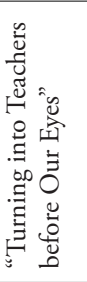 & 等 & $\begin{array}{l}\text { Examinar o desenvolvimento da Identi- } \\
\text { dade Profissional de professores em início } \\
\text { de carreira inscritos no último ano de } \\
\text { formaçáo docente. } \\
\text { Professores Finalistas inscritos no último } \\
\text { ano de formação docente na Universida- } \\
\text { de de Wollongong }\end{array}$ & $\begin{array}{l}\text { Diálogo } \\
\text { profissional } \\
\text { em grupos de } \\
\text { discussão; } \\
\text { Gravaçôes áudio } \\
\text { compartilhado } \\
\text { num site. }\end{array}$ & $\begin{array}{l}\text { - O uso do diálogo profissional tanto no ambiente } \\
\text { físico, como virtual revelou ser uma abordagem va- } \\
\text { liosa para a promoçấo da capacidade reflexiva e para } \\
\text { o desenvolvimento da Identidade Profissional. }\end{array}$ \\
\hline 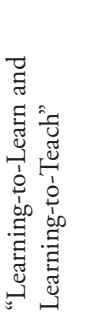 & 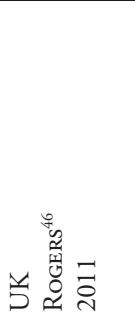 & $\begin{array}{l}\text { Compreender a natureza epistemológica } \\
\text { das crenças dos estudantes em formação } \\
\text { docente, relativamente à profissão, e todo } \\
\text { o seu desenvolvimento e impacto sobre a } \\
\text { Identidade Profissional. } \\
18 \text { Estudantes em formação docente }\end{array}$ & $\begin{array}{l}\text { Questionários; } \\
\text { Grupo Focus; } \\
\text { Grupos de } \\
\text { discussão; } \\
\text { Fórum "online"; } \\
\text { Diário de Bordo } \\
\text { dos estudantes. }\end{array}$ & $\begin{array}{l}\text { - O desenvolvimento do conhecimento epistemo- } \\
\text { lógico acerca do que é ser professor revelou ser um } \\
\text { elemento chave no desenvolvimento profissional dos } \\
\text { estudantes, sendo que os processos de aprendizagem, } \\
\text { dentro de um contexto específico, têm impacto } \\
\text { significativo sobre as Identidades Profissionais dos } \\
\text { estudantes e sobre os seus valores como professores, } \\
\text { ultrapassando a própria matéria de ensino. }\end{array}$ \\
\hline
\end{tabular}

Continua 
QUADRO 2 - Sinopse de estudos relativos à identidade profissional do professor (continuação).

\begin{tabular}{|c|c|c|c|c|}
\hline Título & $\begin{array}{l}\text { País/Autor/ } \\
\text { Ano }\end{array}$ & $\begin{array}{l}\text { Objetivo de Estudo/ } \\
\text { Participantes }\end{array}$ & Instrumento & Principais resultados \\
\hline 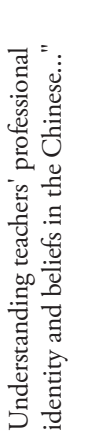 & 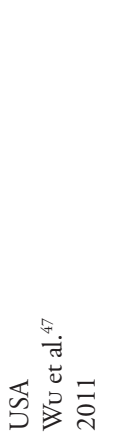 & $\begin{array}{l}\text { Analisar a Identidade Profissional de } \\
\text { professores nativos de Língua Chinesa e as } \\
\text { suas crenças acerca do currículo e práticas } \\
\text { de ensino numa escola americana de } \\
\text { comunidade chinesa. } \\
3 \text { Professores nativos de Língua Chinesa }\end{array}$ & $\begin{array}{l}\text { Entrevistas; } \\
\text { Notas de campo; } \\
\text { Documentos dos } \\
\text { professores. }\end{array}$ & $\begin{array}{l}\text { - A análise dos dados revela que os professores } \\
\text { parecem desenvolver um fraco sentido de Identidade } \\
\text { Profissional, uma vez que o ensino da língua chinesa é } \\
\text { visto como um trabalho "secundário" e "voluntário“; } \\
\text { - Ensinar Chinês parece ajudar os professores a reconec- } \\
\text { tar a linguagem e o conhecimento cultural da China; } \\
\text { - Os contextos de aprendizagem envolvem uma } \\
\text { interaçâo dinâmica entre o professor e o aluno e o } \\
\text { conhecimento cultural dos pais; } \\
\text { - Embora os professores assumam a responsabilidade } \\
\text { de desenvolver a proficiência da língua nos alunos, } \\
\text { eles veem os pais como os principais entraves na } \\
\text { aprendizagem dos alunos ao longo da vida. }\end{array}$ \\
\hline
\end{tabular}

\section{Identidade profissional do professor de Educação Física}

A segunda fase da pesquisa, em que se procurou do Professor na área da Educação Física, integrou identificar estudos acerca da Identidade Profissional seis estudos empíricos, cuja sinopse está descrita no QUADRO 3.

QUADRO 3 - Sinopse de estudos relativos à identidade profissional do professor.

*a) Expetativas de desenvolvimento profissional;

b) Tecnologia dos regulamentos;

c) Debilitação programática;

d) Marginalização política;

e) Debilitação profissional;

f) Jurisdição inadequada; g) Desvalorização de assunto;

h) Pouca tradição de pesquisa;

i) Contradições curriculares;

j) Monopólio da ação do

Estado;

k) Fuga das relações de indução;

l) Articulações de identidade.

\begin{tabular}{|c|c|c|c|c|}
\hline Título & $\begin{array}{l}\text { País/Autor/ } \\
\text { Ano }\end{array}$ & $\begin{array}{l}\text { Objetivo de Estudo/ } \\
\text { Participantes }\end{array}$ & Instrumento & Principais resultados \\
\hline 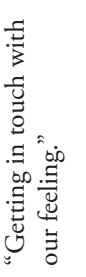 & 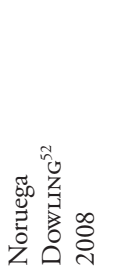 & $\begin{array}{l}\text { Analisar o modo como os formadores no } \\
\text { âmbito da formação inicial de professores } \\
\text { de EF constroem as suas Identidades Pro- } \\
\text { fissionais utilizando as lentes da igualdade } \\
\text { de oportunidades entre sexos. } \\
7 \text { Professores formadores de } 3 \text { Universida- } \\
\text { des de Educação Física }\end{array}$ & $\begin{array}{l}\text { Entrevistas; } \\
\text { Observação; } \\
\text { Análise docu- } \\
\text { mental. }\end{array}$ & $\begin{array}{l}\text { - Os professores formadores parecem evocar fortes } \\
\text { reaçóes emocionais, muitas vezes até sentimen- } \\
\text { tos "negativos" a esta divergência entre gêneros, } \\
\text { no entanto as preocupaçóes com a igualdade de } \\
\text { oportunidades na formação parecem permanecer } \\
\text { nos ambientes de aprendizagem que ainda sáo } \\
\text { influenciados pelo caráter discriminatório. }\end{array}$ \\
\hline 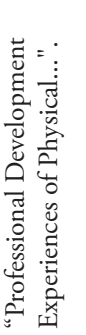 & 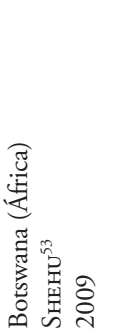 & $\begin{array}{l}\text { Examinar as questóes contextuais que } \\
\text { incidem nas experiências de desenvol- } \\
\text { vimento profissional dos professores de } \\
\text { EF de Botswana, compreender como os } \\
\text { professores interpretam essas experiências } \\
\text { em relação à sua Identidade Profissional. } \\
35 \text { Professores EF do Ensino Secundário } \\
12 \text { professores de EF Universitários }\end{array}$ & $\begin{array}{l}\text { Grupos Focus; } \\
\text { Entrevistas. }\end{array}$ & $\begin{array}{l}\text { - Os resultados revelam uma série de temas* ligados } \\
\text { às desigualdades na formação de professores; } \\
\text { - Os professores de ensino secundário parecem } \\
\text { salientar mais a temática da Debilidade profissional } \\
\text { e da Jurisdição inadequada enquanto os professores } \\
\text { universitários foram particularmente sensível sobre o } \\
\text { tema do Monopólio da ação do Estado e da Margi- } \\
\text { nalizaçáo das pesquisas acadêmicas das suas institui- } \\
\text { çóes, pois sentem a falta de apoio nas investigaçōes } \\
\text { em curso, necessário às suas funçóes profissionais. }\end{array}$ \\
\hline
\end{tabular}


QUADRO 3 - Sinopse de estudos relativos à identidade profissional do professor (continuação).

\begin{tabular}{|c|c|c|c|c|}
\hline Título & $\begin{array}{c}\text { País/Autor/ } \\
\text { Ano }\end{array}$ & $\begin{array}{c}\text { Objetivo de Estudo/ } \\
\text { Participantes }\end{array}$ & Instrumento & Principais resultados \\
\hline 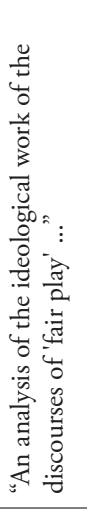 & 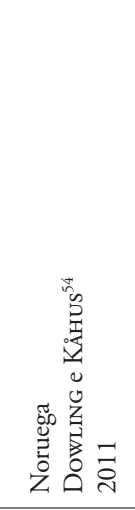 & $\begin{array}{l}\text { Explorar em que medida o PETE ("Phy- } \\
\text { sical Education Teacher Education") pode } \\
\text { nutrir ambientes de aprendizagem equi- } \\
\text { tativos, pelo discurso de profissionalismo } \\
\text { dos professores, numa lente da equidade } \\
\text { de gênero. } \\
8 \text { Formador do Programa PETE } \\
12 \text { Estudantes em formação PETE } \\
5 \text { Supervisores }\end{array}$ & $\begin{array}{l}\text { Entrevistas; } \\
\text { Análise de } \\
\text { conteúdos dos } \\
\text { currículos. }\end{array}$ & $\begin{array}{l}\text { - Os resultados revelaram que o conceito de "fair play", } \\
\text { juntamente com o prevalecente discurso de gênero e } \\
\text { pontos de vista dominantes de profissionalismo do } \\
\text { professor em PETE, estáo na base do "trabalho ideoló- } \\
\text { gico" que sustenta as relaçóes desiguais entre gêneros. } \\
\text { - O discurso de "fair play" baseia-se nos entendimen- } \\
\text { tos do senso comum dos participantes em oposiçâao } \\
\text { a perspectivas teóricas, assim como, o discurso } \\
\text { hegemônico de gênero. } \\
\text { - Invés de desenvolver identidades profissionais que } \\
\text { celebrem a diversidade, a cultura PETE da Noruega } \\
\text { parece continuar uma tradição do professor como } \\
\text { objeto, formando professores estagiários e alunos de } \\
\text { um modo universal, desencarnado e descontextuali- } \\
\text { zado do contexto. }\end{array}$ \\
\hline 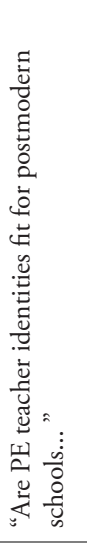 & 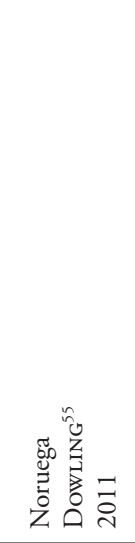 & $\begin{array}{l}\text { Explorar quais os discursos atuais sobre } \\
\text { o profissionalismo, disponíveis dentro da } \\
\text { formação de professores de EF na noruega } \\
\text { (PETE) e, em particular, saber se existe } \\
\text { uma reflexão acerca das necessidades dos } \\
\text { professores na era pós-moderna. } \\
12 \text { Estudantes em formação PETE }\end{array}$ & $\begin{array}{l}\text { Entrevistas; } \\
\text { Análise de } \\
\text { conteúdos dos } \\
\text { currículos. }\end{array}$ & $\begin{array}{l}\text { - Os documentos analisados destacam que os pontos de } \\
\text { vista sobre o profissionalismo no PETE tendem a ser } \\
\text { de natureza normativa, e portanto, não são explicita- } \\
\text { mente fundados em ideias teóricas sobre "boas” práticas } \\
\text { ou sobre entendimentos teóricos acerca do papel do } \\
\text { professor nas escolas pós-modernas; } \\
\text { - Os programas PETE parecem favorecer pouco a } \\
\text { aprendizagem por observaçáo (“apprenticeship-of- } \\
\text { observation”) e parecem acentuar a prática desportiva } \\
\text { (realizada), invés de lhes proporcionar uma compreensão } \\
\text { sólida da EF sobre a qual desenvolvem as mais amplas } \\
\text { identidades profissionais do professor de EF; } \\
\text { - Os discursos dos estudantes acerca da prática de um } \\
\text { bom professor de EF, parecem ser inadequadas para en- } \\
\text { frentar os desafios de trabalhar com alunos socialmente } \\
\text { diversos ou em grupos de professores colaborativos. }\end{array}$ \\
\hline 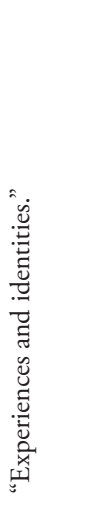 & 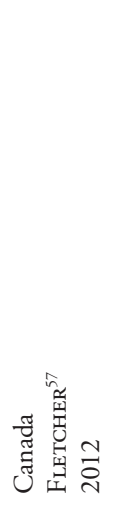 & $\begin{array}{l}\text { Analisar como os estudantes estagiários } \\
\text { desenvolvem as suas identidades profissio- } \\
\text { nais, ao longo do programa de formação, } \\
\text { no ensino elementar de EF. } \\
2 \text { Estudantes-estagiários (EEs) em forma- } \\
\text { ção de professores de EF }\end{array}$ & Entrevistas. & $\begin{array}{l}\text { - A análise crítica às próprias experiências em EF } \\
\text { alterou as suposiçóes iniciais dos EEs acerca do } \\
\text { que implicava e o que significava o ensino de EF, } \\
\text { pelo fato de ambos participantes terem vivenciado } \\
\text { experiências negativas enquanto alunos de EF; } \\
\text { - Os participantes reconheceram diferentes expe- } \\
\text { riências e modos de ensinar na EF, levando-os a } \\
\text { acreditar que os conhecimentos, habilidades e quali- } \\
\text { dades que possuíam poderiam ser úteis no presente } \\
\text { papel como professores de EF; } \\
\text { - Os autores do estudo entendem, que na formação, } \\
\text { é necessário, não só abordar os conteúdos e a } \\
\text { pedagogia da EF, como também ajudar os EEs a } \\
\text { desconstruir e refletir criticamente sobre a EF e o } \\
\text { seu papel enquanto professores. }\end{array}$ \\
\hline
\end{tabular}




\section{Discussão}

\section{Identidade profissional do professor}

Os dados representados no QUADRO 2 revelaram variedade relativamente aos participantes dos estudos, englobando professores em formação, designadamente, estudantes-estagiários (EE), professores em carreira, professores universitários, formadores, supervisores e professores cooperantes. De referir ainda que os professores em foco são oriundos de várias níveis de escolaridade (educadores de infância; pré-escolar; $1^{\circ}, 2^{\circ}$ e $3^{\circ}$ ciclo básico; secundário e ensino superior) e de diferentes disciplinas (Ciências, Línguas, Literatura, Sociologia, Humanidades e Educação Religiosa Cristã).

No que concerne à data de publicaçôes dos estudos, nota-se um recente investimento na pesquisa acerca da Identidade Profissional do professor. Com efeito, no ano de 2008, de 2010 e de 2011 é quando se verifica um maior número de artigos publicados (respetivamente, oito, nove e nove estudos). Já ao nível do local de realização das pesquisas, 14 foram realizados no continente Europeu, oito na América do Norte, oito na Oceânia, cinco no continente Asiático e um no continente Africano.

Relativamente aos instrumentos de investigação, não obstante a variabilidade, a entrevista é o instrumento mais utilizado, seguindo-se os questionários, as reflexôes dos participantes (Narrativas, Diários, Registos/Reflexões e Blogue), os grupos de discussão (Grupo focus e/ou Fórum "online") e ainda a observação e a análise documental. Estes resultados remetem para uma clara predominância de estudos de natureza qualitativa, sendo também evidente a utilização de vários instrumentos em simultâneo, denunciando, assim, a necessidade de estudar o construto da Identidade Profissional por recurso à triangulação de fontes de informação distintas. $\mathrm{Na}$ verdade, se atendermos à sua natureza dinâmica da identidade $^{2}$ e o seu caráter multidimensional ${ }^{3}$, justificase esta necessidade. Este parece ser o modo de se poder aceder à sua complexidade. De fato, atendendo a que a construção de identidade se reporta a um conjunto de fatores cuja influência pode promover modos de ação, percepção e atitudes diversificados, porquanto depende da interpretação que cada indivíduo faz do contexto social, cultural e profissional, a conjugação de diferentes fontes de informação, com uma clara incidência em instrumentos de natureza qualitativa, revela-se vital ao seu entendimento. Com efeito, é esta tipologia de instrumentos que permitem perceber em profundidade os fenômenos em estudo. Não obstante e como exceção, no estudo de $\mathrm{CHEUNG}^{21}$, o propósito foi a construção de um instrumento de natureza quantitativa, mais especificamente uma escala que pretendia medir a Identidade Profissional. Esta escala de 19 itens englobava cinco domínios - o domínio do processo de ensino-aprendizagem, o domínio da formação dos alunos, o domínio do desenvolvimento escolar, o domínio das funções e relações profissionais e o domínio do desenvolvimento e crescimento profissional. De entre os estudos existentes, apenas um estudo ${ }^{28}$ que utiliza questionários, aplicou uma metodologia de caráter quantitativo e de natureza inferencial (medidas comparativas).

Dando, agora, ênfase aos principais resultados dos estudos verifica-se que no estudo de SCHEPENS et al. ${ }^{28}$, o foco foi procurar compreender a Identidade Profissional em relação à interação de algumas variáveis caracterizadoras (características demográficas, traços de personalidade e motivações para a docência) e as variáveis do contexto em que ocorre o processo de formação (apoio e capacidades do corpo docente). Os autores destacaram que os traços de personalidade e as motivações são decisivas na forma como os estudantes interpretam cada uma das suas vivências durante a formação. Do mesmo modo, Ezer et al. ${ }^{30}$ concluíram que as motivações intrínsecas dos estudantes estagiários para o ensino pesam mais no decorrer da sua formação do que as motivações extrínsecas. $\operatorname{LiM}^{44}$ evidencia alguns conceitos que influenciam na construção da Identidade Profissional de estudantes em formação docente, referindo tal como os autores anteriores, as razōes que os levam a investir na carreira docente e a tentativa de se tornarem bons professores. De fato, o estudo de LiM $^{44}$ coloca em evidência que o ímpeto do desenvolvimento profissional destes estudantes são os conhecimentos e as experiências relacionadas com as qualidades docentes e as práticas de ensino. Neste entendimento, está patente a valorização dos percursos pessoais no modo de olhar a Identidade Profissional, que como se sabe é um processo que se inicia antes da formação superior, socialização antecipatória ${ }^{49-50}$, prossegue durante a formação inicial e continua ao longo de todo o percurso profissional ${ }^{51}$, dependendo tanto dos julgamentos dos outros como das suas próprias orientações e autodefinições.

Já $\mathrm{HONG}^{31}$, ao analisar as diferentes percepçôes dos estudantes estagiários e as suas Identidades Profissionais em relação às suas decisões de abandonar a profissão, discorre acerca da identidade profissional 
dos professores recorrendo a um conjunto de fatores: valor, eficácia, comprometimento, emoções, conhecimentos e crenças, e micropolítica. Neste estudo, os autores apontam a carga emocional como sendo a origem da falta de persistência e de comprometimento com a profissão dos estudantes estagiários, que ao revelarem percepções ingênuas e idealistas relativamente à prática real de ensino, acabaram, muitas vezes, por abandonar a profissão. Contudo, outras evidências foram encontradas no estudo de ThOMAs e BeAUCHAMP ${ }^{43}$, em que os participantes, ao enfatizarem a variedade de papéis que tinham de desempenhar, se sentiam prontos para ensinar, encarando os desafios como um modo de sobrevivência, isto embora expressassem dúvidas sobre as suas capacidades. Com efeito, algumas das metáforas dos professores "noviços", participantes deste estudo, revelaram que o desenvolvimento de uma Identidade Profissional durante o primeiro ano de trabalho é um processo gradual, complexo e muitas vezes problemático, que assume diversos contornos. Talvez por isso, CANRINUs et al. ${ }^{40}$ considerem que também a satisfação dos professores no trabalho, a autoeficácia, o compromisso profissional e a mudança no nível da motivação, se assumem como fortes indicadores da Identidade Profissional dos professores, defendendo que a Identidade Profissional não deve ser vista como uma variável composta por uma estrutura uniforme e contínua. Estes estudos, vêm deixar bem claro que, como defende $\mathrm{SACHS}^{4}$, a aquisição da identidade (acrescentamos a identidade do professor) é um processo aberto, negociado e dinâmico.

Ainda noâmbito das motivações e comprometimento dos professores, também o estudo de RoBINSON et al. ${ }^{16}$ apresenta dados que reforçam a noção de que o contexto tem uma forte influência na Identidade Profissional, porquanto é no confronto com as mudanças na prática real, vivenciadas em comunidades sociais de prática, que os sentimentos, o "status" e as relações profissionais e pessoais dos professores são influenciadas. VAHASANTANEN et al. ${ }^{27}$ realçam, igualmente, a influência do contexto na construção da Identidade Profissional, nomeadamente o contexto organizacional do trabalho docente. De fato, os professores participantes deste estudo demonstraram sentir-se mais comprometidos com o trabalho quando tinham condiçôes favoráveis e maior liberdade para as suas orientaçōes práticas e atividades individuais.

Reforçando esta ideia, ABBAS e MCLEAN ${ }^{13}$, na sua pesquisa, colocaram em relevo a vulnerabilidade de um grupo de professores de sociologia, em que o aumento de professores a tempo parcial teve um elevado impacto na qualidade do ensino da sociologia, no desenvolvimento da sociologia e no estatuto profissional dos sociólogos, em resultado do menor interesse moral e prático destes elementos que estão implicitamente envolvidos na "reprodução" da sociologia.

Numa outra vertente, AsSAF $^{20}$ refere que parece que os professores sofrem algumas pressões por parte das instituições, acabando por influenciar a sua capacidade de resposta às necessidades dos alunos, mesmo quando o professor dá prevalência ao ensino centrado no aluno. Este comportamento pode comprometer a responsabilidade e o sentido ético do que deve ser o professor e talvez, por esta razão, a professora participante neste estudo tenha apresentado dificuldades em se manter fiel à sua Identidade Profissional. A noção de identidade institucional, uma das dimensôes da identidade apontadas por $\mathrm{GEE}^{3}$, fica evidente neste estudo, em que a pressão institucional acabou por se sobrepor aos entendimentos individuais, isto é, a estrutura sobrepôs-se à capacidade de agenciamento desta professora.

JephCote e Salisbury ${ }^{29}$ também concordam que estas pressões provocam mudanças nas performances dos professores e uma constante destabilização nos seus trabalhos. No entanto, se por um lado, os professores evidenciaram estar cada vez mais sujeitos a normas externas e códigos de prática, por outro lado, foi evidente que estes exerciam o seu próprio agenciamento, no controle e na construção das suas próprias identidades profissionais, privilegiando mais as necessidades e interesses dos seus alunos. Neste enquadramento, TANG $^{42}$ reforça as consequências das pressōes neoliberais em Hong Kong que ocorrem nos contextos de trabalho dos professores, marcados pela incerteza, a intensificação de trabalho e os mandatos externos de mudanças que tiram aos professores muito tempo e energia nos principais processos de ensino. $\mathrm{O}$ mesmo autor considera que são estas práticas educativas que parecem ameaçar o "desenvolvimento sustentável” da Identidade Profissional dos professores. Pois, apesar da Identidade Profissional ser dinâmica e estar num processo constante de reconfiguração, também necessita de determinada estabilidade para que as bases possam ser construídas.

Em contraponto, O'CONNOR ${ }^{25}$ destaca a necessidade dos professores serem autônomos na tomada de decisões, centrando-se no ensino para os alunos em virtude das exigências institucionalizadas. Até porque, na educação, o campo afetivo e a relação interpessoal entre o professor e o aluno são inevitáveis e, neste campo de intervenção, não existem regulamentos pré-determinados nem soluções institucionalizadas. 
Contudo, além do contexto institucional, a Identidade Profissional é influenciada pelo contexto cultural da sociedade. Como apresentam Wu et al. ${ }^{47}$, os professores parecem desenvolver um fraco sentido de Identidade Profissional quando o seu papel é visto como um trabalho "secundário" ou "voluntário". Neste caso específico, referem-se ao ensino da língua chinesa numa comunidade chinesa EUA. O fato de o seu trabalho ser pouco valorizado pelos pais, que da mesma forma parecem não promover a aprendizagem da língua chinesa dos educandos ao longo da vida, não favorece o desenvolvimento da Identidade Profissional destes professores, embora a interação com a comunidade educativa aumente os seus conhecimentos da língua e da cultura chinesa. Da mesma forma, MoloneY ${ }^{35}$ detecta a interferência da cultura profissional na construção da Identidade Profissional dos professores do pré-escolar e da escola primária. De fato, neste estudo parece evidenciar-se a existência de uma desvalorização dos professores deste nível de ensino, até mesmo em termos de exigência de habilitação para a docência, o que faz com que estes se sintam desrespeitados por outros professores.

Simultaneamente, consciente que as novas reformas educativas promovem alguns antagonismos profissionais, McDougalL ${ }^{34}$ percebe, através dos discursos de alguns professores, que distintas perspetivas frente aos meios educativos, remetem para uma crise de Identidade Profissional. Com efeito, os professores, ora demonstram uma visão tradicionalista, vendo os meios de ensino como um fardo desnecessário, ora "abraçam" a profissão docente com empenho, reconhecendo a necessidade de mudar as prioridades no ensino.

Numa outra dimensão acerca da diversidade e cada vez maior abrangência das funçóes dos professores, SMIT et al. ${ }^{36}$ referem que apesar dos professores serem sobrecarregados, não abdicam da melhoria do ensino. Não obstante, é necessário um melhor entendimento acerca dos valores, das crenças, das normas e da cultura de ensino para que a classe docente possa exercer com sucesso e dentro dos mesmos objetivos.

Tendo em conta que a construção da Identidade Profissional é um processo que se inicia antes da formação superior, prossegue durante a formação inicial e continua ao longo do exercício profissional, SWENNEM et al. ${ }^{23}$ procuraram compreender como é que os professores formadores desenvolvem a sua identidade no contexto da formação de professores, concluindo que é no desempenho diário, na conquista de novos conhecimentos e habilidades, que as suas identidades vão sendo (re)construídas.
Com efeito, ao longo do tempo as tarefas e funções dos formadores têm vindo a aumentar, sendo, em parte, essas mudanças e exigências que os impede da necessidade de procurar novos conhecimentos e competências de modo a melhorar as suas capacidades e, consequentemente, desenvolverem as suas identidades profissionais.

No estudo de DOECKE ${ }^{15}$ é evidenciado o papel da reflexão no desenvolvimento profissional, sendo que os estudos de LueHMENN ${ }^{22}$ e LueHMENN e Tinelli ${ }^{24}$ descrevem a "escrita" como principal estímulo à reflexão das suas práticas, neste caso específico, a escrita no blogue. Em ambos os estudos defende-se que o fato de os professores "narrarem" os acontecimentos das suas aulas, refletindo sobre elas, e de partilharem ideias com outros profissionais, promove a resolução de problemas em comum, a cooperação e a troca de conhecimentos e estratégias, conduzindo a uma contínua atualização de conhecimentos científicodidáticos e, consequentemente, ao desenvolvimento profissional. Nesta perspetiva, COHEN $^{32}$ destaca uma série de estratégias discursivas, nomeadamente a "personal storytelling" e a "analytical talk", para reforçar a importância do discurso reflexivo na prática profissional compartilhada entre os professores, sendo que são os próprios professores participantes do estudo, que se reconhecem como constantes aprendizes frente aos desafios educacionais do meio onde se encontram. Neste mesmo sentido, mas no contexto formativo, URZUA e VASQUEZ ${ }^{26}$ defendem ser importante que os professores mentores, incentivem a reflexão prospectiva dos professores principiantes. De fato, através das reuniōes de orientação os autores deste estudo perceberam que se criam ambientes favoráveis à exposição de planos ou à discussão de resultados, à análise das possibilidades de intervenção e à reflexão acerca das práticas pedagógicas dos professores iniciantes. Para ManteI e KerVIN ${ }^{45}$, estes grupos de discussão, que designam de diálogo profissional, são uma abordagem fundamental no desenvolvimento da capacidade reflexiva e na construção da Identidade Profissional. Estes autores reforçam o diálogo profissional tanto em espaço físico como em espaço virtual (fórum "online"). Na verdade, através da análise deste meio de partilha e confronto de ideias, Sutherland et al. ${ }^{37}$ perceberam transformaçōes positivas no desenvolvimento de estudantes estagiários em formação docente. Enquanto partilhavam algumas tarefas de caracter obrigatório e reflexivo, os estudantes tornaram-se capazes de desenvolver uma postura mais profissional e consciente em relação à docência. De referir que neste processo de construção identitária, 
a dimensão discursiva da identidade, indicada por $\mathrm{GEE}^{3}$, marca presença.

Ainda no que concerne ao desenvolvimento dos estudantes em formação docente, LAMOTE e ENGELS ${ }^{33}$ valorizam a experiência de estágio no desenvolvimento enquanto professores. Estes autores demonstram que ao longo desta vivência os estudantes vão criando um entendimento mais realista quanto ao seu papel como docentes, desenvolvendo uma concepção do ensino mais centrada no aluno e na qualificação dos alunos e menos na organização da aula e na autoeficácia.

Estudos como os de RoBInson et al. ${ }^{16}$ e TEN DAM e $\mathrm{BLOM}^{17}$ valorizam a formação de professores em comunidade de prática ${ }^{a}$, como um meio optimizador na construção da Identidade Profissional. Além disso, os autores consideram importante entender o modo como os professores constroem as suas identidades, enquanto interagem com os alunos, com os professores e com outros intervenientes da comunidade educativa, assim como, entender o modo como a identidade cultural influencia a (re)construção da Identidade Profissional do professor. A questão da comunidade e da cultura nos processos de construção da Identidade Profissional é demais evidenciada por Kostogriz e PEELER $^{18}$, que definem a comunidade como sendo uma construção ambivalente, que tanto une as pessoas como cria limites e barreiras na integração social dos profissionais. Neste estudo, a comunidade profissional de professores revela-se ora inclusiva, ora exclusiva. Assim, menciona-se o exemplo de professores de origem estrangeira que são inseridos num novo contexto. Tal fato pode-se justificar pelos padrões de pensamento e prática de ensino que parecem divergir tanto dentro como entre cada país, acabando por limitar um pouco a "competência intercultural dos professores".

Não obstante se possa observar algumas limitações quando os professores são de origem diversa, o estudo de Robinson et al. ${ }^{16}$ evidencia que as experiências "dos membros da equipe em comunidade de prática" são benéficas ao desenvolvimento profissional, pois permitem a troca e a construção de novos conhecimentos e estratégias para aprender a resolver problemas das novas formas de trabalho. Deste modo, em conjunto facultam uma Identidade Profissional, resultado da assimilação do que é individual e coletivamente relevante para a cultura profissional onde se insere a comunidade docente. Talvez por esta razão, TEN DAM e BLOM ${ }^{17}$ consideraram pertinente compreender de que modo os estudantes estagiários seriam capazes de interagir em comunidade, tendo concluído que estes se sentem mais responsáveis pelas suas aulas e menos responsáveis pelas atividades da escola, enquanto comunidade profissional, uma vez que não se sentem parte integrante da escola onde estagiam. Timostsuk e UGAST ${ }^{38}$, ao analisarem os discursos de estudantes em formação docente, entenderam que centram muito a sua atenção nas experiências pessoais e emotivas, nos fracassos e nos sucessos, discriminando um pouco os contextos sociais e as relaçôes pessoais da comunidade educativa.

Percebe-se, pois, que independentemente da influência da multiplicidade de espaços na aprendizagem de ser professor, o estágio assume um papel preponderante na formação docente. Como indica Rogers ${ }^{46}$, embora o desenvolvimento epistemológico acerca do que é ser professor seja um elemento chave no desenvolvimento profissional dos estudantes, sem os processos de aprendizagem e os conhecimentos contextualizados no ambiente específico de ação, o impacto sobre as suas Identidades Profissionais deixa de ser tão significativo. Na verdade, é fundamental que os estudantes para professores consigam "abraçar" a profissão além do conhecimento da própria matéria de ensino ${ }^{46}$. Como reforçam TEN DAM e BLOM ${ }^{17}$, o contexto real proporcionado pelo estágio permite aos estudantes estagiários aprender experimentando e refletindo - "aprendendo errando". No entanto, é importante realçar que nesta perspectiva de "aprender errando", tal como demonstram EzER et al. ${ }^{30}$, importa que os estudantes estagiários tenham consciência do papel elementar do "professor mentor" e das suas instruçóes didáticas durante o processo de estágio, fundamentalmente para as construções identitárias enquanto futuros profissionais docentes.

Neste mesmo âmbito formativo, no estudo de $\mathrm{KATZ}^{41}$ a experiência de estágio promoveu mudanças no pensamento dos candidatos a professores sobre o ensino e aprendizagem das Ciências, tendo sido destacadas duas grandes categorias: a) pedagogia transformadora; e b) entusiasmo no ensino e aprendizagem das Ciências. De destacar que em cada um dos casos exemplificados pelos autores foram encontradas mudanças nos modelos mentais dos candidatos que refletiam claramente as suas Identidades Profissionais enquanto futuros professores de Ciências. Já AdebniA ${ }^{48}$ destaca três grandes mudanças nos estudantes em processo de formação: a) a passagem da conformidade das ideologias promovidas pelas autoridades, pelas teorias de alguns autores e pelas instruçôes dos livros didáticos (metodologias de ensino memorizadas), a uma visão crítica e autônoma sobre elas, sabendo fundamentar as suas ideias; b) a passagem de uma visão instrumentalista, onde o ensino era entendido como um instrumento para 
promover os seus próprios interesses (rendimento, aquisição de experiências ou continua melhoria do próprio aprendizado em línguas, e ocupação do tempo), evidenciando a falta de missão com a profissão, a uma orientação crítica/transformadora, alterando e reorganizando, ao longo do curso, alguns dos seus objetivos e prioridades; e finalmente, c) a passagem de uma visão linguística e técnica a uma visão educacional, em que os futuros professores passam a perceber que devem ir além do mero cumprimentoeducacional do ensino e ajudar os alunos a tornarem-se pensadores críticos e cidadãos ativos. Como indica ADEBNIA ${ }^{48}$, os professores desenvolveram uma visão transformadora e utópica acerca do ensino, porquanto todo o processo de desenvolvimento e reconstrução das suas identidades atravessaram diferentes níveis e modos de entendimento de natureza utópica, que os fizeram olhar para o ensino como uma ferramenta para o desenvolvimento mental do indivíduo, de transformação social e de emancipação. Neste processo, a redefinição das suas identidades enquanto professores foi percepcionada pelo autor como sendo uma tarefa mais exigente que a construção do conhecimento para a realização das tarefas.

No que diz respeito àqueles que podem ser entendidos como indicadores da Identidade Profissional, CATTLEY $^{19}$ enumerou a relação com os outros, a consciência do mundo social e político além da sala de aula, a consciência da partilha e ajuda, bem como, a consciência dos benéficos da observação e análise da própria ação e da ação dos outros.

Em suma, os resultados destacam a reflexão, a partilha, a cooperação e a experimentação como ações fundamentais no desenvolvimento da Identidade Profissional, sendo que o contexto real de ação e as comunidades de prática são apontados como sendo ambientes favoráveis a este desenvolvimento.

\section{Identidade profissional do professor de Educação Física}

Os estudos denunciam variabilidade na tipologia de participantes, havendo, contudo, maior predominância em intervenientes que participam na formação de Professores de Educação Física, designadamente professores universitários (formadores) e estudantesestagiários (formandos). Em termos de temporalidade, verifica-se que o ano de 2011 foi o mais produtivo (três estudos), havendo já um estudo publicado em 2012. Nos anos precedentes apenas se identificaram dois artigos. Assim, não obstante a investigação nesta temática da Identidade Profissional do professor de
Educação Física ainda ser escassa, é visível que começa a haver um maior investimento. Em termos de locais em que os estudos foram desenvolvidos, o continente Europeu foi onde houve maior incidência (três), dos restantes um foi realizado no continente Asiático, outro no continente Africano e outro na América do Norte.

Relativamente aos instrumentos utilizados, mais uma vez os resultados reforçam o caráter qualitativo no estudo desta temática, sendo que a entrevista é o instrumento mais recorrente, seguido da análise documental, das sessões de Grupo Focus e da Observação. O Questionário foi apenas utilizado num estudo que tinha como objetivo analisar e comparar a autoestima de professores estagiários em Programas de formação de Ensino Especial, nomeadamente, na área da Educação Física. A noção que o estudo da Identidade necessita de dados de várias fontes e que recolham dados em profundidade, tal como nos estudos da identidade dos professores em geral, também se verifica nos professores de Educação Física.

A preocupação com as desigualdades existentes nos processos de formação de professores está patente em alguns estudos ${ }^{52-54}$. Com efeito, enquanto $\mathrm{SHEHU}^{53}$ se centra num leque de temas ligados às desigualdades na formação docente relativamente às debilidades profissionais, à jurisdição e à falta de apoio em investigações necessárias às funções profissionais dos professores, reforçando a influência do meio institucional no desenvolvimento das identidades dos professores, Dowling ${ }^{52}$ e Dowling e KArbus ${ }^{54}$ focam-se nas desigualdades de oportunidade entre gêneros que consideram influenciar negativamente no desenvolvimento de identidades profissionais que celebrem a diversidade. Já DowLING e KÅrbus ${ }^{54}$ alertam para a existência de uma formação tradicional, particularmente a existente na Noruega, onde o professor ainda é visto como um objeto; e onde se forma professores estagiários e alunos de um modo universal, desencarnado e descontextualizado. De fato, num estudo anterior, DowLING ${ }^{52}$ já tinha colocado em relevo que embora os professores formadores reconhecessem emoções negativas relativamente à divergência entre gêneros e se preocupassem com esses fatores, os ambientes de aprendizagem proporcionados aos formandos ainda eram influenciados pelo caráter discriminatório. Ainda neste contexto de formação, DowLING ${ }^{55}$, ao explorar os discursos atuais acerca do profissionalismo nos Programas de Formação de Professores de Educação Física (PETE), na tentativa de procurar saber se existe uma reflexão acerca das necessidades atuais dos professores, chega à conclusão que os PETE 
são tendencialmente de natureza normativa. Pois, os objetivos pedagógicos e as decisões tomadas em torno do PETE, colocam mais em evidência "O quê?" e o "Como?" da Educação Física do que o "Porquê?" de ensinar. Assim, confrontando os dados oriundos da análise documental dos PETE e a informação resultante das entrevistas, DowLING ${ }^{55}$ percebe que os pontos de vista acerca do profissionalismo não são explicitamente fundados em ideias sobre "boas práticas" ou sobre o verdadeiro papel do professor nas escolas pós-modernas; pelo contrário, o autor percepciona que os programas PETE acentuam a prática desportiva dos estudantes em formação docente e desvalorizam a aprendizagem pela observação ("apprenticeship-of-observation”), que possibilitaria uma melhor compreensão do ensino da Educação Física. Neste contexto, os participantes do estudo de DowLING ${ }^{55}$ evidenciaram discursos sobre as práticas de "bom professor" inadequadas aos desafios da escola e que interferiam no desenvolvimento das suas Identidades Profissionais. Por outras palavras, os estudantes em formação definiam objetivos específicos para os alunos apenas em torno da matéria de ensino, desvalorizando o desenvolvimento pessoal e social dos seus alunos, bem como as variáveis socioeconômicas. Os participantes não tinham em conta a diversidade para a qual devem estar preparados, nem tão pouco eram preparados para os constantes e contínuos desafios da Educação Física, sendo que foi perceptível que eram estas limitaçóes acerca do ensino de Educação Física, exclusivamente centrado no conteúdo da aula, que limitavam o desenvolvimento das Identidades Profissionais dos participantes. O mesmo autor considera que os programas PETE parecem ter muito pouca influência na transformação das percepções "erradas" dos estudantes em formação para a docência, que vêm um "bom professor de Educação Física” como um "executante competente". Neste enquadramento, o autor entende que os programas PETE não fornecem ferramentas conceituais que permitam aos participantes prever a multiplicidade das suas Identidades Profissionais adequando-as ao contexto e aos alunos socialmente diferentes.

Centrando-se na reflexão e análise crítica de estudantes estagiários em formação para a docência em Educação Física, FLETCHER ${ }^{57}$ colocou em evidência a influência das experiências vividas enquanto alunos de Educação Física, nas suposições iniciais destes estudantes em formação acerca do que é o ensino de Educação Física. No seu entendimento, os estudantes estagiários ao reconhecerem outros modos de ensinar em Educação Física, aprenderam a valorizar conhecimentos, habilidades e qualidades que possuíam e eram úteis para o desempenho das suas funções na escola. $\mathrm{O}$ mesmo autor acresce que a promoção da formação é necessária no sentido de promover o desenvolvimento profissional dos professores de Educação Física, sendo que refere que é necessário, não só abordar os conteúdos e a pedagogia da Educação Física, como também ajudar os estudantes a desconstruir e a refletir criticamente sobre a Educação Física e o seu papel enquanto professores.

De acordo com os critérios de seleção determinados nesta revisão sistemática, perante os artigos de "peer review" obtidos, a investigação no âmbito da Identidade Profissional do professor tem vindo a aumentar, sendo que ao nível do professor de Educação Física ainda é escassa. Os instrumentos de recolha de dados mais utilizados são as entrevistas, as reflexôes dos participantes (Narrativas, Diários, Registos/Reflexões e Blogue), os grupos de discussão (Grupo Focus e/ou Fórum "online”) e ainda a observação e a análise documental. Assiste-se, assim, a uma predominância dos processos qualitativos em detrimento dos quantitativos, justificado, em parte, pelo fato do objetivo ser descrever, no sentido de melhor compreender e interpretar. A procura de captar a natureza dinâmica e aberta do construto da identidade está assim patente nesta perspectiva.

Os resultados dos presentes estudos dão ênfase ao desenvolvimento profissional como sendo o principal meio de (re)construção da Identidade Profissional, realçando que a sua construção é um processo "precocemente" ativado pelas vivências e crenças anteriores à formação inicial de professores, que continuam durante a formação e no decorrer de toda a carreira profissional. Neste entendimento, pode-se concluir que a Identidade Profissional é uma construção contínua resultante do exercício das funções docentes, seja qual for o contexto e o período em que as interações com a comunidade escolar ocorram (com alunos, funcionários, encarregados de educação, professores, diretores).

Neste sentido, algumas investigaçôes advogam a necessidade de melhorar e reformular o modo como se formam professores, designadamente os professores de Educação Física, em que os estudos identificados foram na sua quase totalidade centrados nos processos de formação e nos estudantes em formação. Estes estudos colocam em evidência a ineficácia de alguns programas de formação nos processos de configuração da Identidade Profissional dos futuros professores.

A reflexão, a partilha, a cooperação e a experimentação prática foram identificadas como 
características indispensáveis ao desenvolvimento da Identidade Profissional, sendo que o contexto real de ação, vivenciado em estágio, e a aprendizagem em comunidade de prática, foram identificados como ambientes favorecedores ao seu desenvolvimento.

Da revisão efetuada, percebeu-se que são poucos os estudos que investigam a Identidade Profissional no âmbito da Educação Física. Ficou clara a necessidade de continuar a investir na pesquisa nesta área disciplinar. Com efeito, o professor de Educação Física na construção da sua Identidade Profissional terá, certamente, alguns traços comuns aos demais professores, porém é igualmente expetável que a especificidade desta disciplina e o seu contexto de lecionação introduzam algumas particularidades na Identidade Profissional deste professor.

\title{
Nota
}

a. Entende-se por comunidade prática a vivência em contexto real da prática profissional realizada em grupo, constituindose como um espaço onde a partilha é essencial para o sucesso ${ }^{58}$.

\begin{abstract}
Teacher professional identity: a systematic review study

The present study is a systematic review of literature focused on the empirical studies conducted about teacher's Professional Identity. The research used electronic databases (ISI Web of Knowledge, ERIC, SPORTDiscus and SCOPUS ) in peer review articles, published between 2001 and 2011. The research equations used were "Professional Identity" AND "teacher", in Title and "Professional Identity" AND "Teacher" AND "Physical Education", in Abstract. After applied the inclusion criteria's 42 articles were integrated. Content analysis was used with categories defined a priori: 1) focus of the study; 2) year and place of publication; 3) objectives; 4) participants; 5) instruments and 6) main conclusions. The results showed an increase in research in the professional identity and in qualitative methodologies. The professional development was pointed as a central element in the process of professional identity (re)construction. The research in Physical Education teachers is still scarce.
\end{abstract}

KEY WORDS: Professional identity; Teacher; Professional development; Physical education; Systematic literature review.

\section{Referências}

1. Fontes A, Fonseca E, Duarte S. Identidade profissional [dissertação]. Lisboa(PT): Universidade de Lisboa, Faculdade de Ciências, Departamento de Ciências da Educação; 2003.

2. Giddens A. Modernidade e identidade pessoal. Oeiras: Celta; 1994.

3. Gee J. Identity as an analytic lens for research in education. Rev Res Educ. 2000;25:99-125.

4. Sachs J. Teacher professional identity: competing discourses, competing outcomes. J Educ Policy. 2001;16:149-61.

5. Lopes MAC. Libertar o desejo, resgatar a inovação : a construção de identidades profissionais em docentes do $1^{\circ} \mathrm{CEB}$. 1999 [tese]. Porto(PT): Universidade do Porto, FPCE; 1999.

6. Dubar C. A socialização: construção das identidades sociais e profissionais. Porto: Porto; 1997.

7. Jurasaite-Harbison E. Reconstructing teacher's professional identity in a research discourse: a professional development opportunity in an informal setting. Trames. 2005;9:59-176.

8. Pimenta SG, Anastasiou LGC. Docência no ensino superior. São Paulo: Cortez; 2002.

9. Petticrew M, Roberts H. Systematic reviews in the social sciences: a practical guide. Cornwall: Blackwell; 2006.

10. Savin-Baden M, Major CH. Qualitative research synthesis: the scholarhip of integration in practice. In: Savin-Baden M, Major CH, editors. New approaches to qualitative research: wisdom and uncertainty. Abingdon: Routledge; 2010. p.108-18. 
11. Kofinas A, Saur-Amaral I. 25 years of knowledge creation processes in pharmaceutical contemporary trends. Comport Organ Gest. 2008;14:257-80.

12. Denyer D, Tranfield D. Using qualitative research synthesis to build an actionable knowledge base. Manage Decision. 2006;44:213-27.

13. Abbas A, McLean M. Becoming sociologists: professional identity for part-time teachers of University Sociology. Brit J Sociol Educ. 2001;22:339-52.

14. Dalli C. Being an early childhood teacher: images of professional practice and professional identity during the experience of starting childcare. New Zeal J Educ Stud. 2002;37:73-85.

15. Doecke B. Professional identity and educational reform: confronting my habitual practices as a teacher educator. Teach Teach Educ. 2004;20:203-15.

16. Robinson M, Anning A, Frost N. "When is a teacher not a teacher?": knowledge creation and the professional identity of teachers within multi-agency teams. Stud Continuing Educ. 2005;27:175-91.

17. Ten Dam GTM, Blom S. Learning through participation: the potential of school-based teacher education for developing a professional identity. Teach Teach Educ. 2006;22:647-60.

18. Kostogriz A, Peeler E. Professional identity and pedagogical space: negotiating difference in teacher workplaces. Teach Educ. 2007;18:107-22.

19. Cattley G. Emergence of professional identity for the pre-service teacher. Int Educ J. 2007;8:337-47.

20. Assaf LC. Professional identity of a reading teacher: responding to high-stakes testing pressures. Teach Teach: Theo Pract. 2008;14:239-52.

21. Cheung HY. Measuring the professional identity of Hong Kong in-service teachers. J In-service Educ. 2008;34:375-90.

22. Luehmann AL. Using blogging in support of teacher professional identity development: a case study. J Learn Sci. 2008;17:287-337.

23. Swennen A, Volman M, Van Essen, M. The development of the professional identity of two teacher educators in the context of Dutch teacher education. Eur J Teach Educ. 2008;31:169-84, 2008.

24. Luehmann AL, Tinelli L. Teacher professional identity development with social networking technologies: learning reform through blogging. Educ Media Int. 2008;45:323-33.

25. O'Connor KE. "You choose to care": teachers, emotions and professional identitity. Teach Teach Educ. 2008;24:117-26.

26. Urzua A, Vasquez C. Reflection and professional identity in teachers' future-oriented discourse. Teach Teach Educ. 2008;24:1935-46.

27. Vahasantanen K, Hokka P, Etelapelto A, Rasku-Puttonen H, Littleton K. Teachers' professional identity negotiations in two different work organisations. Vocations Learn. 2008;1:131-48.

28. Schepens A, Aelterman A, Vlerick P. Student teachers' professional identity formation: between being born as a teacher and becoming one. Educ Stud. 2009;35:361-78.

29. Jephcote M, Salisbury J. Further education teachers' accounts of their professional identities. Teach Teach Educ. 2009;25:966-72.

30. Ezer H, Gilat I, Sagee R. Perception of teacher education and professional identity among novice teachers. Eur J Teach Educ. 2010;33:391-404.

31. Hong JY. Pre-service and beginning teachers' professional identity and its relation to dropping out of the profession. Teach Teach Educ. 2010;26:1530-43.

32. Cohen JL. Getting recognised: teachers negotiating professional identities as learners through talk. Teach Teach Educ. 2010;26:473-81.

33. Lamote C, Engels N. The development of student teachers' professional identity. Eur J Teach Educ. 2010;33:3-18.

34. McDougall, J. A crisis of professional identity: how primary teachers are coming to terms with changing views of literacy. Teach Teach Educ. 2010;26:679-87.

35. Moloney M. Professional identity in early childhood care and education: perspetives of presschool and infant teachers. Irish Educ Stud. 2010;29:167-87.

36. Smit B, Fritz E, Mabalane V. A conversation of teachers: in search of professional identity. Aust Educ Res. 2010;37:93-106.

37. Sutherland L, Howard S, Markauskaite L. Professional identity creation: examining the development of beginning preservice teachers' understanding of their work as teachers. Teach Teach Educ. 2010;26:455-65.

38. Timostsuk I, Ugaste A. Student teachers' professional identity. Teach Teach Educ. 2010;26:1563-70.

39. Bryan H, Revell L. Performativity, faith and professional identity: student religious education teachers and the ambiguities of objectivity. Brit J Educ Stud. 2011;59:403-19. 
40. Canrinus ET, Helms-Lorenz M, Beijaard D, Buitink J, Hofman A. Profiling teachers' sense of professional identity. Educ Stud. 2011;37:593-608.

41. Katz P, McGinnis JR, Hestness E, et al. Professional identity development of teacher candidates participating in an informal science education internship: a focus on drawings as evidence. Int J Sc Educ. 2011;33:1169-97.

42. Tang SYF. Teachers' professional identity, educational change and neo-liberal pressures on education in Hong Kong. Teacher Development. 2011;15:363-80.

43. Thomas L, Beauchamp C. Understanding new teachers' professional identities through metaphor. Teach Teach Educ. 2011;27:762-9.

44. Lim HW. Concept maps of Korean EFL student teachers' autobiographical reflections on their professional identity formation. Teach Teach Educ. 2011;27:969-81.

45. Mantei J, Kervin L. Turning into teachers before our eyes: the development of professional identity through professional dialogue. Aust J Teach Educ. 2011;36:1-17.

46. Rogers G. Learning-to-learn and learning-to-teach: the impact of disciplinary subject study on student-teachers' professional identity. J Curriculum Stud. 2011;43:249-68.

47. Wu HP, Palmer DK, Field SL. Understanding teachers' professional identity and beliefs in the Chinese heritage language school in the USA. Lang Cult Curriculum. 2011;24:47-60.

48. Abednia A. Teachers' professional identity: contributions of a critical EFL teacher education course in Iran. Teach Teach Educ. 2012;28:706-17.

49. Flores MA, Day C. Contexts which shape and reshape new teachers' identities: a multi-perspective study. Teach Teach Educ. 2006;22:219-32.

50. Cornelissen JJ, Wyk AS. Professional socialization: an influence on professional development and role definition. South Afr J High Educ. 2007;21:826-41.

51. Albuquerque A, Pinheiro C, Batista P. Study of professional perspetives evolution during the initial training in préservice PE teachers in institutions of higher education public and private. In: Wallian N, Poggi MP, Musard, M, editors. Coconstruire des saviors: les métiers de l'intervention dans les APSA. Besançon: Université de Franche-Comté; 2008. Actes de la 4ème Biennale de l' Association pour la Recherche sur l'Intervention en Sport.

52. Dowling F. Getting in touch with our feelings: the emotional geographies of gender relations in PETE. Sport Educ Soc. 2008;13:247-66.

53. Shehu J. Professional development experiences of physical education teachers in Botswana: epistemological implications. Teach Dev. 2009;13:267-83.

54. Dowling F, Kåhus S. An analysis of the ideological work of the discourses of 'fair play' and moral education in perpetuating inequitable gender practices in PETE. Phys Educ Sport Pedagog. 2011;16:197-211.

55. Dowling F. 'Are PE teacher identities fit for postmodern schools or are they clinging to modernist notions of professionalism?' A case study of Norwegian PE teacher students' emerging professional identities. Sport Educ Soc. 2011;16:201-22.

56. Oz AS, Gumus SS, Kirimoglu H. An investigation of special and physical education pre-service teachers' vocational self-esteem: egitim arastirmalari-eurasian. J Educ Res. 2011;11:107-25.

57. Fletcher T. Experiences and identities: pre-service elementary classroom teachers being and becoming teachers of physical education. Eur Phys Educ Rev. 2012;18:380-95.

58. Wenger E. Communities of practice: learning, meaning and identity. Cambridge: Cambridge University Press; 1998.

\section{Agradecimentos}

Os autores agradecem o financiamento da Fundação para a Ciência e Tecnologia (FCT) subordinado à temática "O papel do estágio na (re)construção da Identidade Profissional no contexto da Educação Física”, com a referência PTDC/ DES/115922/2009. 


\begin{tabular}{r|l} 
ENDEREÇO & \\
Patrícia Gomes & \\
Faculdade de Desporto & Recebido para publicação: 27/01/2012 \\
Universidade do Porto & Revisado: 09/11/2012 \\
R. Dr. Plácido Costa, 91 & Aceito: 30/01/2013 \\
4200-450 - Porto - PORTUGAL & \\
e-mail: pgomes@fade.up.pt &
\end{tabular}

Rev Bras Educ Fís Esporte, (São Paulo) 2013 Abr-Jun; 27(2):247-67 • 267 